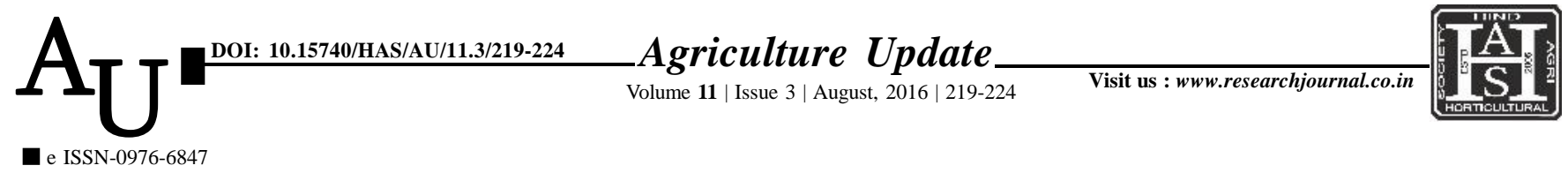

\title{
Research Article: Assessing differential knowledge and attitude level apropos eco-friendly practices (EFP) among the vegetable growers
}

\section{- NEERAJA PATEL AND SANDEEP CHOUHAN}

Article Chronicle: Received :

08.02.2016;

Revised :

15.06.2016;

Accepted :

28.06.2016

KEY WoRDS:

Knowledge level, Eco-friendly management practices, Vegetable
SUMMARY : Management of eco-friendly farming is focussed on the whole farm system and its interactions with climate, environment, social as well as economic conditions, rather than considering the farm as comprises of individual enterprises. The study was conducted in Indore district of Madhya Pradesh with 120 vegetable growers of 10 villages which were selected randomly. All the selected farmers were interviewed personally using a well-structured interview schedule. For analysis of collected data, descriptive statistics (frequency and percentage) and analytical statistics in this study was used. The finding reveals that the higher percentage of vegetable growers (64.17\%) had low knowledge of technology. This may be due to lack of awareness of scientific technology and lack of exposure of about improved technologies in agriculture. Majority 59.16 per cent of vegetables growers were in the category of favourable attitude towards use of eco-friendly management practices.

How to cite this article : Patel, Neeraja and Chouhan, Sandeep (2016). Assessing differential knowledge and attitude level apropos eco-friendly practices (EFP) among the vegetable growers. Agric. Update, 11(3): 219-224, DOI : 10.15740/HAS/AU/11.3/219-224.

\section{NEERAJA PATEL}

Krishi Vigyan Kendra, BADWANI (M.P.) INDIA

See end of the article for authors' affiliations 